\title{
Resistance response of fifteen sweet potato genotypes to scab disease (Sphaceloma batatas) in two growing sites in East Nusa Tenggara, Indonesia
}

\author{
YOSEP SERAN MAU \\ Faculty of Agriculture, Universitas Nusa Cendana. Jl. Adisucipto, Penfui, Kupang 85001, East Nusa Tenggara, Indonesia, Tel./fax.: +62-380-881085, \\ email: yosepmau@yahoo.com
}

Manuscript Received: 5 April 2018. Revision Accepted: 13 May 2018.

\begin{abstract}
Mau YS. 2018. Resistance response of fifteen sweet potato genotypes to scab disease (Sphaceloma batatas) in two growing sites in East Nusa Tenggara, Indonesia. Trop Drylands 2: 5-11. Scab disease is one of most prevalent problems of agricultural crops, including sweet potato, in tropical and sub-tropical regions. This study aimed to evaluate and determine the scab resistance levels of local sweet potato genotypes from Nusa Tenggara Timur (NTT) Province, Indonesia, and to identify sweet potato genotypes with good resistance levels to scab disease. Field experiments were carried out in two growing locations involving potential sweet potato clones from NTT Province. The experiment was carried out in the fields employing a Randomized Block Design with a mono-factorial treatment design in each location. The treatment assigned was sweet potato genotype, each consisting of two replicates. The variables observed were disease severity that was assessed at 2, 4, 6, and 8 weeks after inoculation (WAI), which then was used to calculate the Area Under the Disease Progress Curve (AUDPC) of the disease severity. The ANOVA of AUDPC was used to determine the treatment effect, and the disease severity at 8 WAI was used to assess scab resistance level of the sweet potato genotypes tested. The study results showed highly significant differences in disease severities among the tested sweet potato genotypes within each trial location. The majority of the genotypes tested were classified Resistant or Moderately Resistant to scab disease, except the check clone SLM-01 and KRA-01 that were, respectively, Susceptible and Moderately Susceptible to scab disease. The majority of sweet potato genotypes evaluated were consistent in their resistance performance in the two trial locations.
\end{abstract}

Keywords: Sweet potato, genotype, scab disease, resistance

\section{INTRODUCTION}

Scab disease is one of the most destructive diseases of sweet potatoes in the sub-tropical and tropical regions of the world. Scab disease has been reported to cause yield loss of sweet potato of about 30-65\% in Indonesia (Saleh and Rahayuningsih 2013; Rista et al. 2017) and 60\% in Papua New Guinea (Jackson and McKenzie 1991). In Indonesia, the disease has been recorded to be widespread in sweet potato productions centers, such as Papua, Bali, Jawa, and Nusa Tenggara (Saleh and Rahayuningsih 2013; BPS Indonesia 2015).

Scab disease in sweet potato is caused by the fungus Sphaceloma batatas Saw. (Anamorph) or Elsinoe batatas (Teleomorph) (Jackson and McKenzie 1991). This pathogen infects leaves and stems with early symptoms of tiny, circular to elliptical or elongate, brown spots or lesions. In favorable weather conditions, the symptoms may reach the top leaves, and the buds become twisted (Nayga and Gapasin 1986; Clark and Moyer 1988; Sumartini et al. 2006). High disease intensity may slow down the development of the leaves so that the leaves become curly and distorted, the petioles become shorter and twisted, and the stems grow wrinkled. Severe disease infection may result in low tuber production or total plant loss (Nayga and Gapasin 1986; Moyer et al. 1989; Ames et al. 1997).

The use of fungicide has been so far the primary control measure of sweet potato scab disease (Jackson and McKenzie 1991) as this method is known to be more comfortable in its application and the effect is immediately seen. This chemical control method, however, is, in many cases, neither affordable by the poor farmers and nor environmentally friendly. Therefore, the use of scabresistant sweet potatoes varieties is considered more efficient and economically visible in controlling the disease. Nevertheless, scab resistant superior varieties are now limitedly available and hardly affordable by the farmers. The production of scab-resistant varieties in sweet potato can be initiated through the selection of local germplasm as a source of scab resistance, which then is further employed for generation of superior scab-resistant varieties through cross-breeding program.

Several local sweet potato genotypes from East Nusa Tenggara (Nusa Tenggara Timur; NTT) Province of Indonesia have been identified and selected for several traits. A few of this local germplasm were found to be drought-tolerant (Mau et al. 2008; Mau 2012), resistant or moderately resistant to sweet potato weevil Cylas formicarius (Mau et al. 2011), and also high yielding and stable across environments (Mau et al. 2009; 2013). This local germplasm with such superior traits is invaluable genetic resource that can be used as parental sources for generation of more superior varieties and can also be directly registered as superior local varieties for germplasm 
conservation and the property rights of the local community represented by the local government.

In addition to the above-mentioned superior variety traits, resistance to scab disease is another important trait that needs to be possessed by the sweet potato genotypes from NTT Province. The scab disease is one of the many factors that caused the low sweet potato productivity in NTT $\left(6.98 \mathrm{t} \mathrm{ha}^{-1}\right)$ (BPS NTT 2015) that is much lower than the national level (16.05 $\mathrm{t} \mathrm{ha}^{-1}$ ) (BPS Indonesia 2015). Local sweet potato clones with good scab resistance will enable them to be used to increase the sweet potato productivity and production and also more suitable to be used as superior parental sources as well as registration of superior local varieties. To date, information on scab resistance level of local sweet potato clones/genotypes from NTT is lacking. This study was carried out with the following objectives: (i) to evaluate and determine the scab resistance levels of local sweet potato genotypes from NTT, (ii) to identify sweet potato genotypes with good resistance level to scab disease.

\section{MATERIALS AND METHODS}

\section{Research location}

The present study was carried out in two sites in East Nusa Tenggara (NTT) Province, Indonesia, i.e., Detubapa Village (630 m asl), Detusoko Sub-District, Ende District and Kesetnana Village (810 m asl), Mollo Selatan SubDistrict, Timor Tengah Selatan (TTS) District. S. batatas inoculum was obtained from the infected plants in the field and prepared in the Plant Pathology Laboratory, Faculty of Agriculture, Universitas Nusa Cendana, Kupang, Indonesia for inoculations of the plants in the fields. The study was conducted for five months during April-August, 2011.

\section{Research design and materials}

This study employed a Randomized Block Design in each of the two growing locations. The assigned treatments were sweet potato genotype consisting of 13 local clones from East Nusa Tenggara Province and two check varieties. The check varieties were Kidal (the scab-resistant variety) kindly provided by Indonesian Legumes and Tuber Crops Research Institute (Balai Penelitian Tanaman Aneka Kacang dan Umbi; Balitkabi), Malang, East Java, Indonesia, and SLM-01 (the scab-susceptible clone) collected from Sumber Arum Village, Sleman District, Yogyakarta, Indonesia. In total, 15 genotypes were evaluated in each location; i.e., Detubapa Village, Ende District, and Kesetnana Village, TTS District. A total of 60 experimental units were evaluated in two trial locations.

\section{Research procedures}

In each location, the experimental field was previously cultivated with maize plant. The field was first cleared from the plant debris and plowed at $30-40 \mathrm{~cm}$ depth to allow easy preparation of the planting plots. The planting field in each location was divided into two blocks as replicates, and each block was further sub-divided into single row planting plots of $3 \mathrm{~m} \times 1 \mathrm{~m}$ size as the experimental unit. The number of planting plots prepared in each block/replicate was 15 to fit the number of sweet potato genotypes evaluated. The distance between blocks was $100 \mathrm{~cm}$ while that between plots within a block was 50 $\mathrm{cm}$. Placement of treatments within each block was carried out randomly.

The planting materials were prepared from the sweet potato shoot cuttings of $25-30 \mathrm{~cm}$ in length or consisted of 3-4 stem internodes. Five sweet potato cuttings were planted in each plot with a planting space of $50 \mathrm{~cm}$ within the plot. Basal fertilizers containing $30 \mathrm{~g}$ Urea plot $^{-1}$ (100 $\mathrm{kg}$ Urea ha-1), $30 \mathrm{~g} \mathrm{TSP} \mathrm{plot}^{-1}$ (100 kg TSP ha $\left.{ }^{-1}\right)$, and $45 \mathrm{~g}$ $\mathrm{KCl}^{-1}\left(150 \mathrm{~kg} \mathrm{KCl} \mathrm{ha}{ }^{-1}\right)$ were applied at the time of planting.

Scab resistance evaluation was carried out by artificially inoculating the tested plants in the field. $S$. batatas conidia were obtained from the field-infected plants. The infected plant parts were cultured in a PDA medium in the laboratory to get a pure culture of $S$. batatas. Fourteen days old $S$. batatas pure culture was then used to prepare the inoculum for artificial inoculation using a conidial concentration of $2 \times 10^{6}$ conidia $\mathrm{mL}^{-1}$. The inoculum was prepared in a hand sprayer of $1000 \mathrm{~mL}$ size and was applied by spraying the sweet potato plants six weeks after sowing. Each sample plant was sprayed using the prepared inoculum until all the leaves and stems were thoroughly wet.

\section{Observation and data analysis}

The main variable observed in the present study was the disease severity, which was recorded four times during the study, i.e., at 2, 4, 6, and 8 weeks after inoculation (WAI) or at $8,10,12$, and 14 weeks after planting (WAP). The observation was done on ten upper leaves of the main stem of each plant in each plot (five plants per plot). The scab disease severity was calculated using the following formula:

$$
I=\frac{\sum(n x v)}{Z x N} \times 100 \%
$$

Where: $\mathrm{I}=$ disease severity, $\mathrm{n}=$ number of leaves in each disease category/score, $\mathrm{v}=$ disease score, $\mathrm{Z}=$ the highest disease score, $\mathrm{N}=$ total number of leaves observed in each plant. The mean disease severity of each plot was obtained from the average of all individual plant disease severities within each plot.

The disease score was determined following the method of Zuraida et al. (1992) as follows: 0: healthy, no apparent infection; 1: visible scabs on leaves, petioles, and stems > $0-20 \%$; 2 : scabs on leaves, petioles, and stems $>20-40 \%$; 3: scabs on leaves, petioles, and stems > 40-60\%; 4: scabs on leaves, petioles, and stems $>60-80 \%$, and 5: scabs on leaves, petioles, and stems $>80 \%$.

Disease severity at the last assessment ( $8 \mathrm{WAI}$ ) was used to classify the scab resistance level of the tested sweet potato genotypes. Classification of sweet potato scab resistance was performed based on the range of disease severity as the followings: $0-10 \%=$ "Resistant" (R), 11$20 \%=$ "Moderately Resistant" (MR), 21-30\% = 
"Moderately Susceptible" (MS), >30\% = "Susceptible" (S) (Mukelar et al. 1994).

Meanwhile, disease severities during the study, i.e., at 2, 4, 6, and 8 WAI were used to calculate the Area Under the Disease Progress Curve (AUDPC) following the formula by Campbell and Madden (1990):

$$
A U D P C=\sum_{i}^{n-1}\left(\frac{Y_{i}+Y_{i+1}}{2}\right)\left(t_{i+1}-t_{i}\right)
$$

Where: $\mathrm{Yi}=$ disease severity at the $\mathrm{i}^{\text {th }}$ observation, $\mathrm{n}=$ the last disease assessment (number of assessment), $\mathrm{t}=$ period of assessment

\section{RESULTS AND DISCUSSION}

\section{Isolation and identification of $S$. batatas}

The scab-infected plant leaves from the field were brought to the laboratory and were cultured in PDA medium to obtain pure culture for isolation and identification of the pathogen. The pure culture of $S$. batatas (Figure 1.A) shows white hyphae while the fungal conidia are elliptical (Figure 1.B). This observed morphological pure culture characteristics of $S$. batatas were similar to the results of the previous study by Martanto (2010). We then concluded that the scab-infected plant leaves taken from the field were caused by the fungus $S$. batatas. Thus, the pure culture was then used to produce $S$. batatas inoculum for evaluation of scab resistance in sweet potato genotypes from NTT Province.

\section{The observed symptoms of scab disease}

The tested plants showed early signs of reddish-brown spots/pustules on the stems and petioles, which then ruptured to form scabies symptoms. Rupture of the spots caused exfoliation of the epidermis which later resulted in a sunken scab symptom. In severe infections, the scab disease caused leaves in the young shoots to become curly and distorted; even no new leaves/stalks were produced at all. Most of the scabies symptoms were found in stems and petioles with varying lesion severities which depends on the sweet potato genotypes.

In mild disease infection, only a few scabies spots were observed on the affected plant parts, but in severe disease infection, the leaves appeared curly and dwarfed. The susceptible check clone SLM-01 exhibited severe scab symptoms on the stems, petioles, and young shoots while the resistant check variety Kidal suffered only a mild infection. Almost all local sweet potato clones from NTT Province generally showed just mild scab disease symptoms.

The observed scab symptoms in the present study were nearly similar to those observed in the previous studies (Nayga and Gapasin 1986; Clark and Moyer 1988; Moyer et al. 1989; Ames et al. 1997). These similar symptoms indicate the successful artificial inoculation in the field, even though the disease evaluation was carried out during the dry season, where the environmental conditions in NTT Province were, in general, not favorable for scab disease development. The two growing locations that are located at a medium altitude (about 600-800 m asl) might have been quite favorable to allow the artificial scab inoculation in the field was successful.

\section{The progress of scab disease during the experiment}

The development of scab disease severity during the observation period is presented in Table 1. At two weeks after inoculation (WAI), the observed disease severity was still below $10 \%$ except for the susceptible check SLM-01 that suffered $18.55 \%$ infection in Kesetnana and $13.50 \%$ in Detubapa. Consistently, the susceptible check SLM-01 demonstrated high disease severities in each of the two locations. Disease severity of the tested sweet potato genotypes tended to increase along with the increase in time after inoculation or along with the rise in the plant's age.

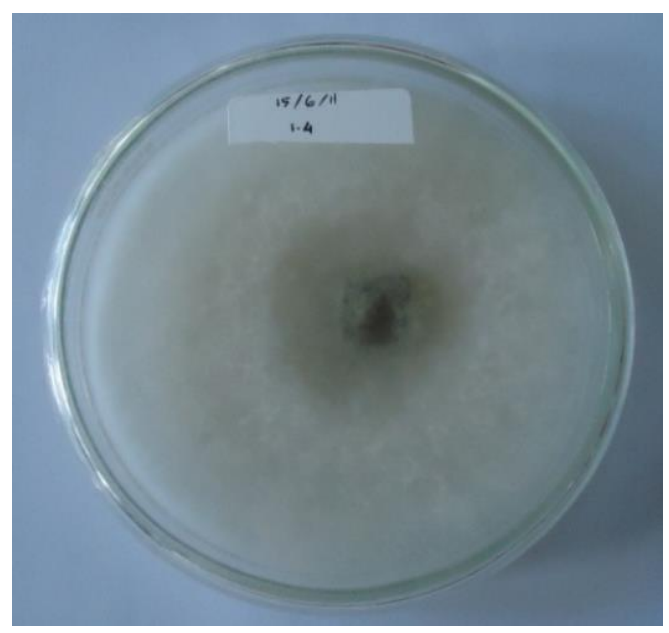

A

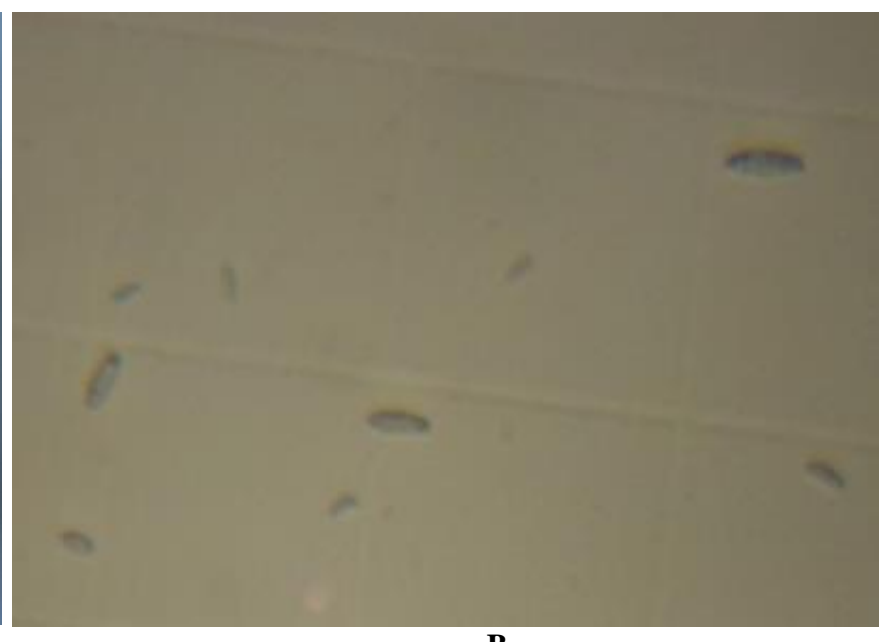

B

Figure 1. Pure culture and microscopic characteristics of the fungus $S$. batatas. A. Pure culture appearance at seven days after culture, B. Shape of $S$. batatas conidia isolated from the pure culture 
Table 1. The progress of disease severity (\%) at two growing sites: Kasetnana village in Timor Tengah Selatan District and Detubapa village in Ende District

\begin{tabular}{|c|c|c|c|c|c|c|c|c|}
\hline \multirow{3}{*}{$\begin{array}{c}\text { Sweet potato } \\
\text { genotype }\end{array}$} & \multicolumn{8}{|c|}{ Growing site } \\
\hline & \multicolumn{4}{|c|}{ Kesetnana } & \multicolumn{4}{|c|}{ Detubapa } \\
\hline & 2 WAI & 4 WAI & $6 \mathrm{WAI}$ & 8 WAI & 2 WAI & 4 WAI & $6 \mathrm{WAI}$ & 8 WAI \\
\hline EBS-01 & 0.42 & 0.50 & 1.70 & 2.00 & 0.00 & 0.33 & 0.50 & 0.67 \\
\hline HK-02 & 0.11 & 0.09 & 0.78 & 1.00 & 0.00 & 3.50 & 5.67 & 6.33 \\
\hline KIDAL & 3.30 & 4.73 & 8.25 & 11.00 & 0.33 & 1.50 & 2.17 & 3.00 \\
\hline KRA-01 & 2.64 & 2.86 & 8.36 & 11.00 & 5.83 & 9.50 & 13.00 & 18.33 \\
\hline LB-01 & 2.50 & 2.40 & 9.00 & 10.00 & 0.50 & 3.83 & 6.17 & 7.17 \\
\hline NBN-01 & 0.18 & 0.18 & 0.95 & 1.00 & 0.33 & 1.00 & 1.83 & 2.67 \\
\hline NLK-01 & 4.05 & 4.32 & 7.29 & 9.00 & 0.00 & 3.00 & 4.00 & 5.17 \\
\hline NPL-01 & 0.24 & 0.28 & 1.60 & 2.00 & 0.33 & 2.33 & 3.17 & 3.67 \\
\hline ON-02 & 0.72 & 0.80 & 2,96 & 4.00 & 2.83 & 5.83 & 6.83 & 7.67 \\
\hline $\mathrm{ON}-06$ & 1.75 & 2.75 & 4.05 & 5.00 & 0.50 & 0.50 & 2.00 & 3.00 \\
\hline ON-07 & 0.80 & 0.95 & 4.50 & 5.00 & 0.17 & 1.67 & 2.33 & 2.83 \\
\hline ORM-02 & 0.81 & 0.72 & 2.22 & 3.00 & 0.67 & 0.83 & 1.33 & 1.83 \\
\hline SEO-01 & 3.60 & 4.08 & 5.46 & 6.00 & 0.00 & 1.67 & 3.00 & 4.00 \\
\hline SLM-01 & 18.55 & 19.25 & 31.15 & 35.00 & 13.50 & 17.33 & 20.83 & 23.83 \\
\hline SOE-02 & 0.47 & 0.49 & 0.89 & 1.0 & 1.17 & 4.00 & 5.00 & 5.50 \\
\hline
\end{tabular}

Note: WAI = Week After Inoculation, 2 WAI (8 Weeks After Planting/WAP), 4 WAI (10 WAP), 6 WAI (12 WAP), 8 WAI (14 WAP)

Table 1 shows that the disease severity development varied considerably according to sweet potato genotypes as well as the growing locations. In Kesetnana, the highest disease severity was observed in the susceptible check SLM-01 while the lowest severity was shown by local clones NBN-01, HK-02, and SOE-02. The SLM-01 consistently exhibited high disease severity in Detubapa, followed by KRA-1, ON-02, and LB-01. The lowest disease severity in Detubapa was observed in EBS-01, followed by ORM-02 and NBN-01.

Overall, we did observe substantial differences in disease resistance reactions of the evaluated sweet potato genotypes. Even though the growing locations significantly affected the disease severity of the tested sweet potato genotypes; we did observe a tendency that most of the genotypes consistently showed almost similar disease severity at the two different sites except for Kidal, KRA01, NLK-01, and ON-02. The SLM-01 susceptible check consistently demonstrated higher disease severities in both test sites. As with SLM-01, KRA also showed high disease severities in both locations, much higher than most local genotypes. Meanwhile, the resistant check variety Kidal showed much higher disease severity in Kesetnana as compared to the local clones, except for KRA-01 NLK-01 and LB-01, while in Detubapa, Kidal showed a lower disease severity than those of most of the local clones tested.

Observed differences in disease severity at different locations might have been caused by variations in environmental conditions, especially temperature, humidity and sunlight intensity that profoundly influenced the disease development and intensity. Also, other factors that might have affected the observed disease severity differences in the fields were the presence of wind, water droplets, and insects that can facilitate the spread of the pathogens among plants in the field. The existence of these factors may assist the spread of the fungus inoculum from one leaf to the others, most notably to the newly grown leaves, which overall affected the disease intensity as well as the disease progression rate.

\section{AUDPC of scab disease}

Area under the disease progress curve (AUDPC) analysis is an approach used to calculate the severity of the disease that is repeatedly observed over time, and thus the AUDPC data can be subjected to ANOVA to see the effect of the treatment on the observed variables (Campbell and Madden 1990). ANOVA results revealed a significant effect of sweet potato genotypes $(\mathrm{P}<0.01)$ on AUDPC of scab disease severities during the observation period in each of the two locations. In Kesetnana, the highest AUDPC of disease severity was observed in the susceptible check SLM-01 (1086.75\%.day), followed by KRA-01, LB01, Kidal and ON-07, while the lowest AUDPC was shown by local clone NBN-01 (12.04\%.day), which was not significantly different from that of other local clones such as HK-01, SOE-02, NPL-02, NLK-01, and ORM-02 (Table 2).

Table 2. Mean AUDPC of scab disease severity (\%.day) of sweet potato genotypes evaluated in two growing sites.

\begin{tabular}{lrlrl}
\hline \multicolumn{1}{c}{ Sweet potato } & \multicolumn{4}{c}{ Growing Site } \\
\cline { 2 - 5 } genotype & \multicolumn{3}{c}{ Kesetnana } & Detubapa \\
\hline EBS-01 & 156.35 & $\mathrm{bcd}$ & 16.33 & $\mathrm{a}$ \\
HK-02 & 29.30 & $\mathrm{ab}$ & 172.67 & $\mathrm{cde}$ \\
KIDAL & 206.19 & $\mathrm{cde}$ & 74.67 & $\mathrm{ab}$ \\
KRA-01 & 261.52 & $\mathrm{e}$ & 484.17 & $\mathrm{f}$ \\
LB-01 & 235.06 & $\mathrm{de}$ & 193.67 & $\mathrm{de}$ \\
NBN-01 & 12.04 & $\mathrm{a}$ & 60.67 & $\mathrm{ab}$ \\
NLK-01 & 70.91 & $\mathrm{abc}$ & 134.17 & $\mathrm{bcd}$ \\
NPL-02 & 41.72 & $\mathrm{ab}$ & 105.00 & $\mathrm{abc}$ \\
ON-02 & 95.34 & $\mathrm{abc}$ & 250.83 & $\mathrm{e}$ \\
ON-06 & 155.65 & $\mathrm{bcd}$ & 59.50 & $\mathrm{ab}$ \\
ON-07 & 164.92 & $\mathrm{bcde}$ & 77.00 & $\mathrm{ab}$ \\
ORM-02 & 68.46 & $\mathrm{abc}$ & 47.83 & $\mathrm{ab}$ \\
SEO-01 & 117.50 & $\mathrm{abcd}$ & 93.33 & $\mathrm{ab}$ \\
SLM-01 & 1086.72 & $\mathrm{f}$ & 795.67 & $\mathrm{~g}$ \\
SOE-02 & 29.79 & $\mathrm{ab}$ & 172.67 & $\mathrm{cde}$ \\
\hline
\end{tabular}

Note: Means within the same column followed by the same letter (s) are not significantly different at $\alpha=0.05$ DMRT 
When grown in Detubapa (630 m asl), the susceptible check SLM-01 also showed the highest AUDPC of disease severity (795.67\%.day), which then followed by KRA-01, $\mathrm{ON}-02$ and LB-01 at the second, the third and the fourth place, respectively; meanwhile the local clone EBS-01 demonstrated the lowest AUDPC (16.33\%.day), which did not statistically differ from other local clones such as NBN01, Left, ON-06, ON-07, ORM-02, and SEO-01.

Higher disease severity AUDPC of the susceptible check SLM-01 indicated a higher disease progress rate in this check genotype as compared to other genotypes evaluated in the present study. Thus, SLM-01 produced a higher accumulated disease severity than other genotypes. In contrast, genotypes with lower disease severity AUDPC exhibited lower disease progress rates and also lower accumulated disease severity during the observation period. Levels/values of the disease severity AUDPC indicate the performance response of the tested sweet potato genotypes concerning their ability to resist/reduce the development and the progress rate of the disease (Campbell and Madden 1990).

In general, data in Table 2 demonstrate a considerable variability of the AUDPC of disease severity, both among the tested sweet potato genotypes in the same growing location and also between the same genotype at different test sites. These variations did occur, presumably, due to differences in the response of the tested genotypes under changing environmental conditions. However, in general, we observed consistency in the disease severity AUDPC rank among the tested genotypes within the two growing locations, where the susceptible check SLM-01 consistently accumulated the highest AUDPC, whereas the local clones ORM-02, NBN-01, and the resistant check Kidal consistently exhibited the lowest AUDPC. Thus, we can deduce from the present study results that variability in disease severity accumulation shown by the tested sweet potato genotypes during the two months observation period was mainly due to the genetic factor, although the effect of the environmental factor, i.e., growing sites, was also apparent.

\section{Scab disease resistance level}

Scab resistance level of tested sweet potato genotypes was determined based on disease severity assessment carried out eight weeks after inoculation or 14 weeks after planting. Scab resistance classification (Table 3) shows that the majority of local sweet potato genotypes were Resistant to scab disease when grown in Kesetnana location. Meanwhile, KRA-01 and the resistant check Kidal were Moderately Resistant whereas the susceptible check SLM01 was Susceptible in the same location. These findings indicated that in Kesetnana growing location, the resistant check Kidal was slightly less resistant than its genetic potential as described in the varietal description while SLM-01 consistently showed a Susceptible reaction as it was supposed to be. Almost similar to the study results in Kesetnana growing location, almost all sweet potato genotypes that were grown in Detubapa location were also classified Resistant, except KRA-01 that was Moderately Resistant and SLM-01 that was Moderately Susceptible to scab disease.
Table 3. Scab resistance levels of tested sweet potato genotypes based on disease severity assessment at eight weeks after inoculation

\begin{tabular}{|c|c|c|c|c|}
\hline \multirow{3}{*}{$\begin{array}{c}\text { Sweet } \\
\text { Potato } \\
\text { Genotype }\end{array}$} & \multicolumn{4}{|c|}{ Growing Site } \\
\hline & \multicolumn{2}{|c|}{ Kesetnana } & \multicolumn{2}{|c|}{ Detubapa } \\
\hline & $\begin{array}{c}\text { Severity } \\
(\%)\end{array}$ & $\begin{array}{c}\text { Resistance } \\
\text { Level }\end{array}$ & $\begin{array}{c}\text { Severity } \\
(\%)\end{array}$ & $\begin{array}{c}\text { Resistance } \\
\text { Level }\end{array}$ \\
\hline EBS-01 & 2.00 & $\mathrm{R}$ & 0.67 & $\mathrm{R}$ \\
\hline HK-02 & 1.00 & $\mathrm{R}$ & 6.33 & $\mathrm{R}$ \\
\hline KIDAL & 11.00 & MR & 3.00 & $\mathrm{R}$ \\
\hline KRA-01 & 11.00 & MR & 18.33 & MR \\
\hline LB-01 & 10.00 & $\mathrm{R}$ & 7.17 & $\mathrm{R}$ \\
\hline NBN-01 & 1.00 & $\mathrm{R}$ & 2.67 & $\mathrm{R}$ \\
\hline NLK-01 & 9.00 & $\mathrm{R}$ & 5.17 & $\mathrm{R}$ \\
\hline NPL-02 & 2.00 & $\mathrm{R}$ & 3.67 & $\mathrm{R}$ \\
\hline $\mathrm{ON}-02$ & 4.00 & $\mathrm{R}$ & 7.67 & $\mathrm{R}$ \\
\hline ON-06 & 5.00 & $\mathrm{R}$ & 3.00 & $\mathrm{R}$ \\
\hline $\mathrm{ON}-07$ & 5.00 & $\mathrm{R}$ & 2.83 & $\mathrm{R}$ \\
\hline ORM-02 & 3.00 & $\mathrm{R}$ & 1.83 & $\mathrm{R}$ \\
\hline SEO-01 & 6.00 & $\mathrm{R}$ & 4.00 & $\mathrm{R}$ \\
\hline SLM-01 & 35.00 & $\mathrm{~S}$ & 23.83 & MS \\
\hline SOE-02 & 1.00 & $\mathrm{R}$ & 5.50 & $\mathrm{R}$ \\
\hline
\end{tabular}

Note: $\mathrm{R}=$ "Resistant", MR = "Moderately Resistant", MS = "Moderately Susceptible", S = "Susceptible".

Data in Table 3 demonstrate that most of the tested sweet potato genotypes exhibited consistent scab resistant reactions in two growing locations. However, the resistance responses of the two check genotypes were slightly deviated along with the change of growing locations. The resistant check, Kidal, was Resistant in Detubapa location but was Moderately Resistant in Kesetnana. Meanwhile, the susceptible check clone, SLM-01, was Susceptible in Kesetnana location but was Moderately Susceptible in Detubapa location. Slight differences in resistance responses observed in the two check genotypes may indicate the presence of genotype by environment interaction effect on the scab resistance phenotype.

Environmental conditions in the field such as temperature and humidity are highly dependent on the local climatic conditions of the growing locations. Although the scab resistance evaluation was done during the dry season, the scab infections in the fields did occur as expected. This might have happened because the growing locations were located at a medium altitude of above $800 \mathrm{~m}$ asl in Kesetnana and above $600 \mathrm{~m}$ asl in Detubapa, where the temperature and humidity were still in the optimal ranges for scab infection. Thus, the scab resistance performance of the tested sweet potato genotypes in the field did very much reflect their genetic potency regarding resistance to scab disease.

Overall, the results showed that 12 out of 13 local genotypes of NTT Province exhibited scab resistant reactions in the fields. This local sweet potato genotype's resistance performance was much higher than that found by Sumartini et al. (2006). By employing the same resistance classification method, Sumartini et al. (2006) observed only one genotype (Genjah Rante) of 14 sweet potato genotypes evaluated that showed Moderately Susceptible reaction while other genotypes were Susceptible to scab. In addition to genetic factors, the higher scab susceptibility 
reactions shown by sweet potato genotypes assessed by Sumartini et al. (2006), presumably, might have been caused by the more favorable growing environmental conditions for scab infection since the evaluation was done during the rainy season.

This is in line with Lenne (1994) who found that the fungus $S$. batatas caused more severe scab infection on sweet potato during wet months (rainy season) as compared to that in the dry season. Additionally, the differences in the virulence levels of $S$. batatas isolates employed could have contributed to the observed variability in the scab resistance levels in the present study and that of Sumartini et al. (2006). Furthermore, in another scab resistance evaluation carried out during dry season by Martanto (2003) in Solo, Central Java, only one of four sweet potato clones evaluated was Resistant to scab, i.e., Muara Takus variety, while the three clones/varieties were, respectively, Moderately Susceptible and Susceptible to scab. In a laboratory experiment, Martanto (2010) also found only one Papuan local clone (Halake), out of four local clones of Papua and the check variety Bogor, that showed scab disease severity of $<10 \%$. Meanwhile, other clones/varieties tested in the same study suffered scab disease severity within the range of $12-22 \%$, which, according to Mukelar (1994) classification, were classified as, respectively, Moderately Resistant and Moderately Susceptible to scab. Using another scab resistance classification according to Ramsey et al. (1988), Widiantini et al. (2015) found about 50\% of 600 sweet potato genotypes of $\mathrm{F} 1$, parental and check populations that showed resistant reaction to scab disease during the dry season 2013 in Sumedang, West Java, Indonesia.

Based on the present study results, it can be said that variability in scab resistance levels of the tested sweet potato genotypes was mainly due to the genetic factor, while the influence of environmental factors, i.e., growing sites, was also apparent. The high scab resistance responses observed in the local sweet potato clones from NTT could be attributed to their genetic background. The fact that most of the local genotypes were resistant to scab might have also occurred due to the limited virulence level of $S$. batatas race used in this study. The local sweet potato clones with good resistance identified in the present study are invaluable genetic resources for future sweet potato breeding programs. Some of these clones had also been determined to be high yielding and stable across environments (Mau et al. 2009; 2013), drought-tolerant (Mau et al. 2008; Mau 2012) and resistant to sweet potato weevil (Mau et al. 2011). All these good traits will enable the selected clones to be used as the parental sources for the development of more superior varieties or can be directly released as superior local varieties.

In conclusion, we find in the present study that scab disease severities and AUDPC among sweet potato genotypes evaluated in two sites varied considerably. Almost all tested sweet potato genotypes exhibited scab resistant reaction except KRA-01 that was moderately susceptible, and SLM-01 that was susceptible in Kesetnana and moderately susceptible in Detubapa. The majority of sweet potato genotypes consistently demonstrated similar resistance responses between the two locations. Scabresistant local sweet potato genotypes observed in the present study are invaluable genetic resources that can be used to generate scab-resistant superior varieties adaptable to the dryland and semi-arid agroecosystem conditions of NTT Province.

\section{ACKNOWLEDGEMENTS}

This research was funded by DP2M DIKTI of Indonesian Ministry of Education and Culture through National Strategic Research Scheme 2011. The author would like to thank A.S.S. Nidwa, Dr. I G.B. Adwita Arsa, and Julinda B. Henuk, for valuable discussions during the research and writing of this article. Special thanks are also extended to Dewi Pattinasarany, Septiani Kahali, Mercy Ndoen, dan Ansel Parera for technical assistance provided during the pathogen inoculum preparation in the laboratory and disease assessments in the fields.

\section{REFERENCES}

Ames T, Smit NEJM, Braun AR, O’Sullivan JN, and Skoglund LG. 1997. Sweet potato: Major Pests, Diseases, and Nutritional Disorders. International Potato Center (CIP). Lima, Peru.

BPS NTT. 2015. The productivity of sweet potato by Regency/City in Nusa Tenggara Timur Province 2010-2015. Statistics of Nusa Tenggara Timur Province, Kupang. [Indonesian]

BPS Indonesia. 2015. The productivity of sweet potato by Province 19932015. Statistics Central Office Indonesia. [Indonesian]

Campbell CL, Madden LV. 1990. Introduction to Plant Disease Epidemiology. John Willey \& Sons, Inc. New York.

Clark CA, Moyer JW. 1988. Compendium of Sweet potato Diseases, Pests, and Disorders. APS Press, St. Paul, MN, USA

Jackson GVH, McKenzie EHC. 1991. Sweet Potato Scab. Pest Advisory Leaflet 24: 1-4. South Pacific Commission, Plant Protection Service, Sufa, Fiji

Lenne JM. 1994. Diseases and pests of sweet potato. Bull Nat Resour Inst 46: 50-51.

Martanto EA. 2003. The role of salicylic acid in host-pathogen interaction in scab disease of sweet potato (Elsinoe batatas). J HPT Tropika 10 (2): 172-177. DOI: 10.23960/j.hptt.210172-177 [Indonesian]

Martanto EA. 2010. The potency of Euphorbia heterophylla L. as an alternative host for scab disease of sweet potato. Jurnal Perlindungan Tanaman Indonesia 9 (2): 92-98. [Indonesian]

Mau YS. 2012. Evaluation of drought tolerance level of sweet potato (Ipomoea batatas L.) germplasm from NTT Province. In: Nurbaity A, Subroto E, Setyowati EY, Stanica F, Bari IN, Wimmers K, Carsono N, Mulyani O, Lehmousloto P, Teng PS, Siswanto SY, Aleksic S (eds.). Proceeding of International Conference on Sustainable Agriculture and Food Security: Challenges and Opportunities. Universitas Padjadjaran Bandung, 27-28 September 2011.

Mau YS, Ndiwa ASS, Arsa IGBA. 2008. The improvement of the genetic potency of Local sweet potato clones from West Timor through the selection of tuber yield and tolerance to drought stress. [Research Report]. Universitas Nusa Cendana. Kupang. Indonesia. [Indonesian]

Mau YS, Ndiwa ASS, Arsa IGBA, Oematan SS. 2009. Evaluation of yield performance of sweet potato clones from West Timor and introduction varieties in Nusa Tenggara Timur. [Research Report]. Universitas Nusa Cendana. Kupang, Indonesia. [Indonesian]

Mau YS, Ndiwa ASS, Arsa IGBA. 2011. Resistance Level of Promising Sweet Potato Clones from East Nusa Tenggara to Sweet Potato Weevil (Cylas formicarius Fab.). Jurnal Hama dan Penyakit Tumbuhan Tropik 11 (2): 139-146. DOI: 10.23960/j.hptt.211139-146 [Indonesian] 
Mau YS, Ndiwa, ASS, Arsa, IGBA, Oematan S. 2013. Growth and yield stability of sweet potato clones across four locations in East Nusa Tenggara. Agrivita 35 (1): 95-102. DOI: 10.17503/Agrivita-2013-351-p095-102

Moyer JW, Jackson GVH, Frison EA. 1989. FAO/IBPGR Technical Guidelines for the Safe Movement of Sweet Potato Germplasm. Food and Agriculture Organization of the United Nations, Rome/International Board for Plant Genetic Resources, Rome. Italy.

Mukelar A, Djaeni M, Anggiani N. 1994. Identifikasi dan distribusi ras Sphaceloma batatas penyebab penyakit kudis pada ubijalar. Risalah Seminar Penerapan Teknologi Produksi dan Pasca Panen Ubijalar Mendukung Agroindustri, Malang, Jawa Timur, Indonesia. [Indonesian]

Nayga J, Gapasin RM. 1986. Effects of stem and foliage scab disease on the growth and yield of VSP-1 sweet potato variety. Ann Trop Res 8: $115-122$.

Ramsey M, Vawdrey L, Hardy J. 1988. Scab (Sphaceloma batatas) a new disease of sweet potatoes in Australia: fungicide and cultivar evaluation. Australian J Exp Agric 28: 137-141. DOI: 10.1071/EA9880137

Rista N, Widiantini F, Roosda AA, Yulia E, Karuniawan A. 2017. Simple Sequence Repeats (SSR) Marker Screening Related to Orange
Fleshed Sweet Potato F1 Genotype Resistance against Scab (Sphaceloma batatas Saw.). 2nd International Conference on Sustainable Agriculture and Food Security: A Comprehensive Approach, KnE Life Sciences, Universitas Padjadjaran, Sumedang, West Java, Indonesia,12-13 October 2015.

Saleh N, Rahayuningsih St.A. 2013. Integrated control of scab disease (Sphaceloma batatas Saw.) on sweet potato. Buletin Palawija 25: 3744. [Indonesian]

Sumartini, Rahayuningsih St.A, Yusuf M. 2006. Scab resistance of potential yellow and purple flesh sweet potato clones. National Seminar on Innovation Technology of Pulse and Tuber Crops to Support the National Food Sovereignty and Energy Sufficiency. [Indonesian]

Widiantini F, Yulia E, Roosda AA, Karuniawan A. 2015. Resistance selection of sweet potato genotypes F1 against scab disease (Sphaceloma batatas). Jurnal Agrikultura 26 (1): 23-29. DOI: 10.24198/agrikultura.v26i1.8457 [Indonesian]

Zuraida N, Bari A, Watimena C, Amir M, Soenaryo R. 1992. Pengaruh penanaman campuran klon ubijalar terhadap penyakit kudis dan hasil. Penelitian Pertanian 12 (3): 119-121. [Indonesian] 